\title{
Antioxidant Potential and Peroxidative State of 'Golden Smoothee' Apples Treated with 1-Methylcyclopropene
}

\author{
Rosa Vilaplana and M. Carme Valentines \\ UdL-IRTA, CeRTA, Post-harvest Dpt., Rovira Roure, 191, 25198 Lleida, Spain
}

Peter Toivonen

Pacific Agri-Food Research Centre, P.O. Box 5000, 4200 Highway 97, Summerland, British Columbia VOH 1Z0, Canada

\author{
Christian Larrigaudière ${ }^{1}$ \\ UdL-IRTA, CeRTA, Post-harvest Dpt., Rovira Roure, 191, 25198 Lleida, Spain
}

AdDitional INDEX words. 1-MCP, storage, senescence, Malus $\times$ domestica

\begin{abstract}
In order to determine the effects that 1-methylcyclopropene (1-MCP) may have on antioxidant metabolism during cold storage, apples (Malus $\times$ domestica Borkh. $\mathrm{cv}$. Golden Smoothee) were treated with $625 \mathrm{~nL} \cdot \mathrm{L}^{-1} 1-\mathrm{MCP}$ immediately after harvest and stored in air for 3 months. Differences in total antioxidant activity and ascorbate levels were determined during storage and related to the activity of the antioxidant enzymes superoxide dismutase [SOD (EC 1.15.1.1)], catalase [CAT (EC 1.11.1.6)], and peroxidase [POX (EC 1.11.1.7)] in pulp. The level of oxidative stress in the pulp tissue was also established by determining changes in levels of hydrogen peroxide and in the content of peroxidative markers during storage. Controls and 1-MCP-treated fruit exhibited similar changes in total antioxidant activity and ascorbate levels. However, significant differences in oxidative stress levels were found between treated and untreated fruit. 1-MCP-treated fruit exhibited lower levels of hydrogen peroxide and significantly lower levels in peroxidative markers, especially at the end of the storage period. In line with this last result, 1-MCP-treated fruit also exhibited greater enzymatic antioxidant potential and, more specifically, a higher level of POX activity. Collectively, these results showed that 1-MCP did not detrimentally affect the antioxidant potential of the fruit and provided evidence to support the hypothesis that the beneficial effects of 1-MCP on ripening are not exclusively limited to its effect on ethylene, but also include direct effects on peroxidation and POX enzyme activity.
\end{abstract}

Apples are climacteric fruit that exhibit a rise in ethylene production and respiration rates during ripening. The storage strategy employed to control ethylene production and respiration is therefore very important to maintain quality in this kind of fruit. In the 1990s, long-term apple storage management almost exclusively involved the management of temperature and gas composition in the storage room [controlled atmosphere storage (CA)]. This approach clearly improved storage duration and maintained apple quality (Kader, 1995). Although the positive effects of CA persist for several days during shelf life, after removal fruit ripen very quickly and must be sold rapidly (Johnston et al., 2002). Furthermore, CA may induce physiological disorders such as internal browning and produce loss of flavor when cold chambers are inadequately managed (Lidster et al., 1990).

Today's increasing use of 1-MCP to extend the commercial life of fruit constitutes an attractive way of improving packinghouse competitiveness. 1-MCP is now registered in many countries, though its first commercial applications date back only a few years (Blankenship and Dole, 2003). 1-MCP blocks ethylene receptors and thus inhibits ethylene action (Sisler et al., 1996; Sisler and Serek, 1997). This compound is therefore able to influence fruit ripening and improves post storage quality in climacteric fruit (Blankenship and Dole, 2003). In recent years, considerable research effort has been put into determining the effects of this

Received for publication 19 Apr. 2005. Accepted for publication 4 Aug. 2005. The authors gratefully acknowledge financial support from the company Rohm and Haas. Special thanks also go to Gemma Reig for technical assistance.

'Corresponding author, e-mail: christian.larrigaudiere@irta.es compound on apple ripening. As an ethylene inhibitor, 1-MCP delays the ripening-related changes that influence quality and especially reduces loss of firmness (Fan et al., 1999a), loss of acidity (Blankenship and Dole, 2003), and color changes in varieties that need to preserve their green freshness. Furthermore, 1-MCP also clearly inhibits superficial scald in a similar or even more effective way than diphenylamine (DPA)(Fan et al., 1999b).

For all these reasons, 1-MCP should be considered a very interesting tool for post-harvest technologists. However, despite these apparent reasons for interest, little is known about the physiological effects of 1-MCP other than its ability to prevent ethylene action. It is important to understand the effects that this product may have on the dietary quality of fruit and particularly on the amount of antioxidants present during storage.

There is now increasing consumer interest in the dietary quality of fruit. Consumer preferences do not only focus on visual and organoleptic quality, but also on the presence of health promoting compounds that need to be preserved in the post-harvest chain. In line with this increasing concern, our work aimed to define the effects that 1-MCP treatment may have on apple antioxidant contents during storage. With this in mind, changes in total antioxidant activity and ascorbate content were monitored in 1-MCP-treated and untreated fruit during storage. Changes in antioxidant enzyme activity, SOD, CAT, and peroxidase POX were also determined to complement this work. Finally, changes in hydrogen peroxide content and in the peroxidative state of the fruit were determined in order to estimate the specific responses of treated and untreated fruit to storage stress. These results are related to quality changes and indicate the relationship existing 
between the 1-MCP related changes in quality and antioxidant metabolism.

\section{Materials and Methods}

Plant material. 'Golden Smoothee' apples were obtained from Lleida (Spain) in Summer 2003. A block of trees planted in 1975 was used for the tests. Orchard characteristics were as follows: conventional fertilization system, Franco class soil texture (according to USDAclassification) and 'Pajam-2' rootstock. Fruit were harvested according to a completely randomized design and at the optimal commercial date, in line with local recommendations established by packinghouses (firmness, soluble solid concentration and acidity values). Fruit were selected on the basis of size and the absence of defects and were stored in experimental chambers $\left(22 \mathrm{~m}^{3}\right)$ for $3,7,15,30$, and $90 \mathrm{~d}$ in air at $1{ }^{\circ} \mathrm{C}$ and $90 \%$ relative humidity.

1-MCP TREatment. Smartfresh (Agrofresh, Inc., Rohm and Haas, Spring House, Pa.) was used to release 1-MCP on the day of harvest, following manufacturer's recommendations. 1-MCP was weighed in powder form $\left(625 \mathrm{~nL} \cdot \mathrm{L}^{-1}, 0.16 \mathrm{~g} \cdot \mathrm{m}^{-3}\right.$ chamber $)$ in a flask. Water was added to release $1-\mathrm{MCP}$ (water temperature = $35^{\circ} \mathrm{C}$; 1 Smartfresh : 5 water ratio) and the flask was immediately sealed. The contents were then continuously stirred for $10 \mathrm{~min}$ to homogenize the mixture. The flask was then taken to the storage chamber, having been previously kept at $0.5^{\circ} \mathrm{C}$, where its cover was removed and treatment started. 1-MCP treatment was carried out overnight $(18 \mathrm{~h})$ and the chamber was then opened and thoroughly aerated. It was subsequently resealed for the duration of the experimental storage period.

DETERMINATION OF TOTAL ASCORBATE CONTENT. Total ascorbate was extracted following the Brubaker et al. (1985) protocol; mixing $25 \mathrm{~g}$ (fresh weight) of pulp with $75 \mathrm{~mL}$ of twice-distilled water and $10 \mathrm{~mL}$ of a solution of $10 \%(\mathrm{w} / \mathrm{v})$ metaphosphoric acid and $5 \%$ 2,3-mercaptopropanol. The homogenate was centrifuged at $20,000 g_{n}$ for $25 \mathrm{~min}$ and the supernatant was made up to $200 \mathrm{~mL}$ with water. Analyses were carried out on an Applied Biosystem (Foster City, Calif.) HPLC, using an $\mathrm{LC}_{18}(25 \mathrm{~cm} \times 4.6 \mathrm{~mm}, 5 \mu \mathrm{m})$ column (Supelco Ltd., Bellefonte, Pa.) and elution was carried out with $6 \%$ methanol $7 \mathrm{~mm}$ in Tetra-n-butylammonium-hydrogensulfat. Elution was isocratic and absorbance was recorded with a $\mathrm{UV} / \mathrm{vis}$ detector at $254 \mathrm{~nm}$ (Wimalasiri and Wills, 1983).

DETERMINATION OF TOTAL ANTIOXIDANT ACTIVITY (DPPH). For each sample, $10 \mathrm{~g}$ of pulp were frozen with liquid nitrogen, triturated and then homogenized with $15 \mathrm{~mL}$ of $13.7 \mathrm{M}$ ethanol. The solution was then vacuum-filtered in the dark, totally evaporated at $80{ }^{\circ} \mathrm{C}$, and finally completed to a final volume of $10 \mathrm{~mL}$ with distilled water. Twenty microliters of extract was then mixed and stirred with $980 \mu \mathrm{L}$ 1-diphenyl-2-picrylhydrazyl (DPPH) in the dark for $30 \mathrm{~min}$ at $4{ }^{\circ} \mathrm{C}$ (Kondo et al., 2002). Initial absorbance (Ai) was measured at $517 \mathrm{~nm}$ on the blank and final absorbance (Af) was measured on the assay after $30 \mathrm{~min}$ incubation. The percentage of inhibition was calculated with the following formula: percent inhibition $=(\mathrm{Ai}-\mathrm{Af}) / \mathrm{Ai}$. Under these conditions, an increase in the inhibition percentage corresponds to an increase in total antioxidant activity.

EXTRACTION OF THE ENZYMES INVOLVED IN ANTIOXIDANT METABOLISM. Pulp tissue (20 g fresh weight) was ground in liquid nitrogen with a pestle and mortar and homogenized in $60 \mathrm{~mL}$ $0.1 \mathrm{~m}$ potassium phosphate buffer ( $\mathrm{pH} 7.8$ ), 2 mм DTT, 5\% $(\mathrm{w} / \mathrm{v})$ polyvinylpolypyrrolidone, $0.1 \mathrm{~mm}$ EDTA and $1.25 \mathrm{~mm}$ polyethylene glycol (Bailly et al., 1996). The homogenate was filtered through two layers of Miracloth (Textil Planas Oliveras S.A., Manresa, Spain) and centrifuged at 20,000 $g_{\mathrm{n}}$ for $15 \mathrm{~min}$ at $4{ }^{\circ} \mathrm{C}$, and then a $2.5-\mathrm{mL}$ aliquot was loaded into a Sephadex G-25 column (PD 10; Pharmacia, Madrid, Spain) equilibrated with $10 \mathrm{~mL} 0.1 \mathrm{M}$ phosphate buffer ( $\mathrm{pH} 7.8)$. The enzymes were eluted with $3.5 \mathrm{~mL}$ of the same buffer. The resulting supernatant was used as an enzyme extract to determine SOD (EC 1.15.1.1) and CAT (EC 1.11.1.6) activity.

Total POX (EC 1.11.1.7) extraction was carried out using the Lurie et al. (1997) protocol. Samples of $10 \mathrm{~g}$ of pulp tissue (fresh weight) were homogenized in $10 \mathrm{~mL}$ phosphate buffer $(0.1 \mathrm{M}$, $\mathrm{pH} 6$ ) with $0.5 \mathrm{~mm}$ cysteine. The extract was filtered through two layers of Miracloth and centrifuged at 30,000 $g_{n}$ for $15 \mathrm{~min}$ at $4{ }^{\circ} \mathrm{C}$. A $2.5-\mathrm{mL}$ sample of the supernatant was then loaded into a Sephadex G-25 column (PD 10) that had previously been equilibrated with $10 \mathrm{~mL}$ phosphate buffer ( $\mathrm{pH} \mathrm{6)}$. The enzyme was eluted with $3.5 \mathrm{~mL}$ of the same buffer.

ANALYSIS OF THE ENZYMES INVOLVED IN THE ANTIOXIDANT METABOLISM. SOD activity was assayed by measuring its ability to inhibit the photochemical reduction of nitroblue tetrazolium (NBT) using the method described by Giannopolitis and Ries (1977). One unit of SOD was considered to be the amount of enzyme required to inhibit NBT reduction by $50 \%$. Catalase activity was measured by the Clairbone (1985) method, following the disappearance of $\mathrm{H}_{2} \mathrm{O}_{2}$ at $240 \mathrm{~nm}$.

POX activity was measured by the method described by Lurie et al. (1997) following changes in the color of the extract at 470 $\mathrm{nm}$ after adding $10 \mathrm{~mm}$ guaiacol and $10 \mathrm{~mm} \mathrm{H}_{2} \mathrm{O}_{2}$.

Except for SOD (see above), enzyme activity was expressed in units of activity (UA) per milligram of protein, with one UA representing the quantity of enzyme responsible for a change in absorbance of 1 absorbance unit per minute. Protein measurements were performed according to Bradford (1976). Data on enzyme activity represent the mean of 6 individual fruit.

DETERMINATION OF HYDROGEN PEROXIDE $\left(\mathrm{H}_{2} \mathrm{O}_{2}\right)$. To determine $\mathrm{H}_{2} \mathrm{O}_{2}$ levels, samples of $15 \mathrm{~g}$ of fresh pulp tissue were homogenized in $20 \mathrm{~mL} \mathrm{5 \%}$ trichloroacetic acid, filtered through two layers of Miracloth and centrifuged at 20,000 $g_{n}$ for $15 \mathrm{~min}$ at $4{ }^{\circ} \mathrm{C} . \mathrm{H}_{2} \mathrm{O}_{2}$ content was determined using the Bioxytech $\mathrm{H}_{2} \mathrm{O}_{2}-560$ colorimetric assay (OXIS International, Portland, Ore.) and following manufacturer's instructions. Assay was based on the oxidation of ferrous ions $\left(\mathrm{Fe}^{2+}\right)$ to ferric ions $\left(\mathrm{Fe}^{3+}\right)$ by hydrogen peroxide under acidic conditions. Ferric ions bound with the indicator dye xylenol orange to form a stable colored complex that was measured at $560 \mathrm{~nm}$. $\mathrm{H}_{2} \mathrm{O}_{2}$ content was expressed as $\mu \mathrm{mol} \cdot \mathrm{kg}^{-1}$ of fresh weight $(\mathrm{FW})$, with each value being the mean of four fruit determinations.

DETERMINATION OF LIPID PEROXIDATION. For this determination, $3 \mathrm{~g}$ of pulp that had previously been frozen with liquid $\mathrm{N}_{2}$ were homogenized in $20 \mathrm{~mL}$ of $20 \mathrm{~mm}$ phosphate buffer ( $\mathrm{pH} \mathrm{7.4).} \mathrm{To}$ prevent sample oxidation, $10 \mu \mathrm{L} 0.1 \mathrm{~m}$ butylated hydroxytoluene (BHT) in acetonitrile were added to $1 \mathrm{~mL}$ of tissue homogenate. The homogenate was centrifuged at 3,000 $g_{n}$ for $10 \mathrm{~min}$ and the supernatant was used for the determination of malonaldehyde (MDA) and 4-hydroxyalkenals (4-HNE). For these determinations the LPO-586 colorimetric assay (OXIS International, Inc.) was followed.

DETERMinAtion OF ETHYLENE PRODUCTION AND RIPENING PARAMETERS. To determine ethylene production, fruit were kept in a room at $20{ }^{\circ} \mathrm{C}$. Ethylene production rate was determined 1 $\mathrm{d}$ after warming using three replicates, each consisting of two apples. Fruit were placed in 1500-mL flasks, which were continu- 
ously ventilated with humidified air at a flow rate of $\approx 1.5 \mathrm{~L} \cdot \mathrm{h}^{-1}$. Ethylene production was measured by taking gas samples from the effluent air of respiration jars and using a $1-\mathrm{mL}$ syringe. Gas samples were injected into a gas chromatograph (model 5890 Series II; Hewlett-Packard, Barcelona, Spain) equipped with an FID detector and an alumina column $(1.5 \mathrm{~m} \times 3 \mathrm{~mm})$. Gas analyses were conducted isothermally at $100{ }^{\circ} \mathrm{C} . \mathrm{N}_{2}$ carrier, air and $\mathrm{H}_{2}$ flows were 45,400 , and $45 \mathrm{~mL} \cdot \mathrm{min}^{-1}$, respectively. The injector and detector temperatures were held at $120^{\circ} \mathrm{C}$ and 180 ${ }^{\circ} \mathrm{C}$, respectively.

Fruit firmness was measured on two opposite peeled sides using a penetrometer (Effegi, Milan, Italy) fitted with an 11mm-diameter flat tip. Soluble solid concentration (SSC) was determined with a digital refractometer (Atago, Tokyo), by measuring the refractive index of the juice extracted from the same fruit that had been used to determine firmness. Data were expressed in percentage terms $(\mathrm{g} / 100 \mathrm{~g}$ fresh weight). Acidity was determined in a mixture containing $10 \mathrm{~mL}$ juice, $10 \mathrm{~mL} \mathrm{H}_{2} \mathrm{O}$ and $0.1 \%$ phenolphthalein, which was titrated with $0.1 \mathrm{~m} \mathrm{NaOH}$ to an end-point $\mathrm{pH}$ of 8.1. Acidity was expressed in grams of malic acid per liter of juice. Data relating to maturity indexes represented means for 30 individual fruit.

Statistical analysis. For the figures, data were analyzed for significant differences by applying variance analysis (ANOVA) using the SAS statistical package (SAS Institute, Cary, N.C.). Data presented in the figures were subjected to mean separation by the least significant difference test, $(P=0.05)$. In Table 1 , the data that concern the changes of ethylene production and quality parameters in control and 1-MCP-treated fruit were subjected to mean separation by Duncan's multiple range test.

\section{Results}

Changes IN ASCORbaTE CONTENT AND IN THE TOTAL ANTIOXIDANT ACTIVITY IN 1-MCP-TREATED AND UNTREATED FRUIT DURING STORAGE. A sharp decrease in ascorbate levels was observed during the first 2 weeks of storage for both control and treated fruit (Fig. 1A). Ascorbate levels subsequently remained stable in untreated fruit but slightly decreased in 1-MCP-treated fruit. After 1 month of storage, ascorbate levels in 1-MCP-treated fruit were slightly lower than in untreated fruit.

Table 1. Effects of 1-MCP treatment on maturity parameters in 'Golden Smoothee' apples stored in air for 3 months.

\begin{tabular}{lccc}
\hline & & \multicolumn{2}{c}{3 months storage } \\
\cline { 3 - 4 } & Harvest & Control & $1-\mathrm{MCP}$ \\
\hline $\mathrm{C}_{2} \mathrm{H}_{4}$ production $^{\mathrm{z}}$ & n.d. & 235.1 & 2.8 \\
$\left(\mu \mathrm{L}^{\mathrm{k}} \mathrm{kg}^{-1} \cdot \mathrm{h}^{-1}\right)$ & & & \\
$\begin{array}{l}\text { Firmness } \\
(\mathrm{kg})\end{array}$ & $7.1 \pm 0.3$ & $5.1 \mathrm{~b}^{\mathrm{w}}$ & $6.9 \mathrm{a}$ \\
$\begin{array}{l}\text { Sugars } \\
(\% \text { soluble solids concn })\end{array}$ & $11.8 \pm 0.3$ & $13.1 \mathrm{a}$ & $12.8 \mathrm{~b}$ \\
$\begin{array}{l}\text { Acidity } \\
\left(\mathrm{g} \cdot \mathrm{L}^{-1}\right)\end{array}$ & $4.8 \pm 0.2$ & $3.8 \mathrm{~b}$ & $4.2 \mathrm{a}$ \\
\hline
\end{tabular}

$\overline{\text { zValues for ethylene production represent means of three replicates of }}$ two fruit each.

yn.d. = not detectable.

$x$ Values represent means of 30 different fruit.

wDifferences between treatments for each time were analyzed by Duncan's multiple range tests. Values in the same row followed by different letters are significantly different at $P=0.05$.
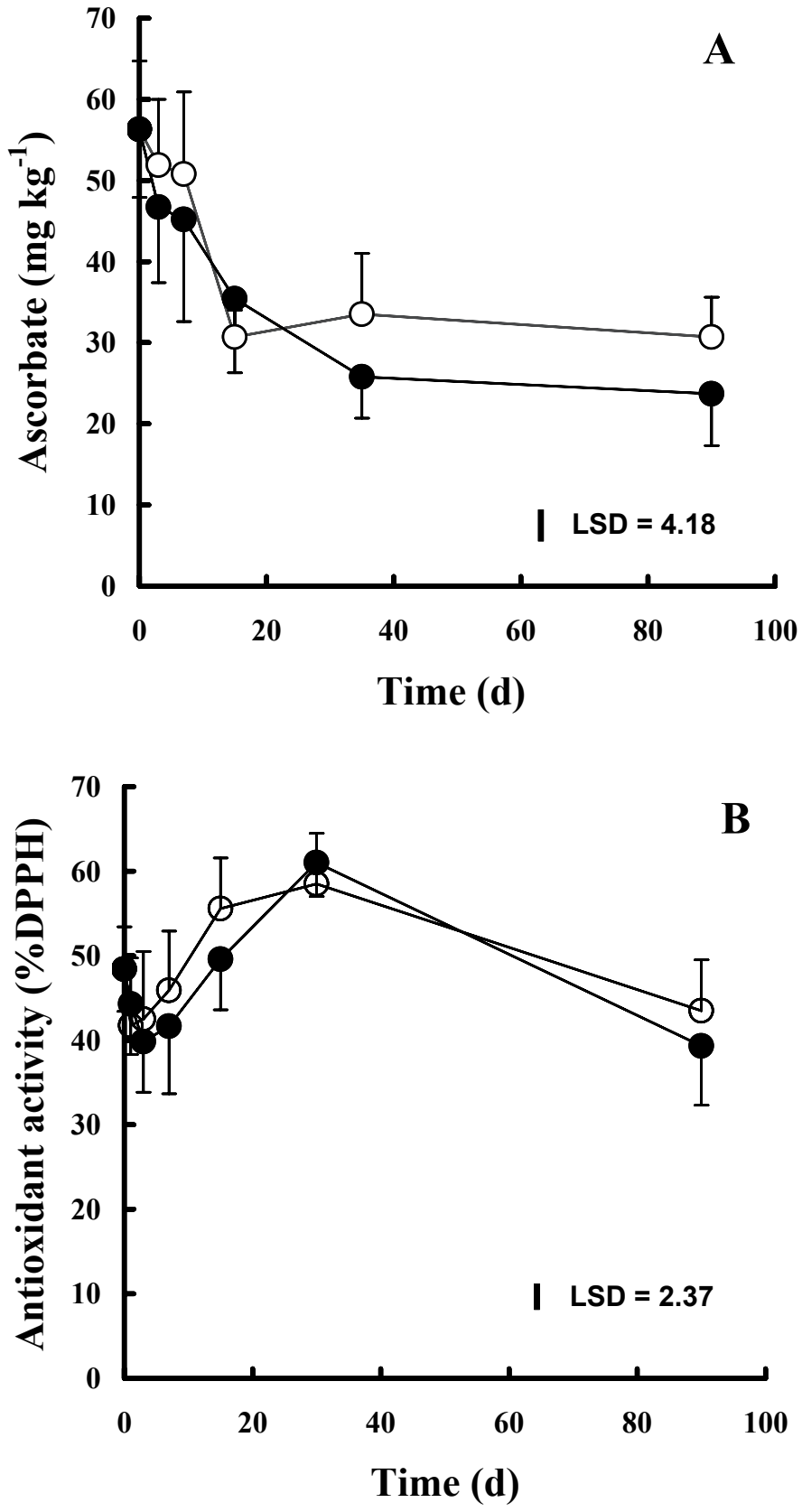

Fig. 1. Changes in ascorbate levels (A) and total antioxidant activity (B) in 'Golden Smoothee' apples treated with 1-MCP during cold storage: Changes in antioxidant activity were measured determining the percentage of decrease in absorbance of a solution of 1-diphenyl-2-picrylhydrazyl (DPPH). An increase in the inhibition percentage corresponds to an increase in total antioxidant activity; ( $\square$ ) control fruit, (@) fruit treated with $625 \mathrm{~nL} \cdot \mathrm{L}^{-1} 1$-MCP. Each point represents the mean \pm SD of six different fruit; bar $=$ LSD at $P=0.05$.

The DPPH method used in this work, measures the ability of a plant extract to absorb radicals and thereby convert the colored 1diphenyl-2-picrylhydrazyl product to an uncolored one. In general, no significant differences in total antioxidant activity were found between the control and the 1-MCP-treated fruit (Fig. 1B). For both treatments, antioxidant activity increased (i.e., percentage DPPH increased) during the first 4 weeks of storage and then steadily declined over the rest of the experimental period.

Changes in ENZymatic antioxidant potential in 1-MCPTREATED AND UNTREATED FRUIT DURING COLD STORAGE. In general, $1-\mathrm{MCP}$ treatment and storage temperature did not cause any 
significant changes in SOD activity, except during the first weeks of storage, when SOD activity was slightly higher in the treated fruit (Fig. 2A). In contrast, a significant increase in CAT activity was observed during first few days of storage for 1-MCP-treated apples. CAT activity later decreased in the treated fruit, but remained higher than in untreated fruit until day 60 of storage (Fig. 2B). A highly significant increase in POX activity was also noted in 1-MCP-treated fruit (Fig. 2C). After a 7-d lag period, POX activity increased sharply in the 1-MCP treatment and this rise persisted until day 90 , when activity peaked with a 20 times greater level of activity than in the controls (untreated fruit).

Changes IN HYDROGEN PEROXIDE LEVELS AND LIPID PEROXIDATION DURING COLD STORAGE. Changes in $\mathrm{H}_{2} \mathrm{O}_{2}$ levels were similar for the control and for 1-MCP-treated fruit: there were slight increases during the first $3 \mathrm{~d}$ of storage and then a sharp decrease until day 30 (Fig. 3A). From day $30, \mathrm{H}_{2} \mathrm{O}_{2}$ levels remained stable until the end of the experimental period. Except during the first $3 \mathrm{~d}$ and at the end of storage, $\mathrm{H}_{2} \mathrm{O}_{2}$ levels in 1-MCP-treated fruit were always significantly lower than in control fruit.

Changes in levels of peroxidation markers (MDA $+4 \mathrm{HNE})$ were also very similar for control and 1-MCP-treated fruit (Fig. 3B). In both cases, levels of peroxidation markers remained stable during the first week of storage, then significantly increased until day 30 of storage and finally increased, but much more gradually, until the end of the experimental period. It should, however, be noted that significantly higher levels of these markers were found in control fruit than in 1-MCP-treated fruit after 3 weeks of storage.

EFFECTS on RIPENING. 1-MCP treatment also significantly reduced ethylene production throughout storage (Table 1). In consequence, treated fruit remained significantly firmer and showed higher acidity, even after 3 months of storage (Table 1). In contrast, only slight differences in SSC content were found between treated and untreated fruit. These differences in quality parameters were maintained throughout the shelf life period [for up to $7 \mathrm{~d}$ (results not shown)].

\section{Discussion}

Although organoleptic quality has always been a major concern for consumers, health-promoting compounds are currently becoming more relevant. Ascorbic acid is particularly important for daily nutrition and directly related to the state of human welfare. In plants, ascorbic acid plays an important role in the detoxification of activated oxygen and in the removal of $\mathrm{H}_{2} \mathrm{O}_{2}$ (Foyer et al., 1991). High levels of ascorbate in fruit favors stress compensation and a decrease in this compound is often considered a symptom of fruit senescence (Borracino et al., 1994) and a factor associated with physiological disorders during storage (Pintó et al., 2001; Veltman et al., 1999). A significant decrease in ascorbate was found in 'Golden Smoothee' apples during the first weeks of storage. Ascorbate levels decreased similarly in control and 1-MCP-treated fruit over the whole experimental period. This showed that the 1-MCP treatment did not induce a loss in ascorbate and therefore did not detrimentally affect the nutritional value of the fruit with respect to that particular nutrient. This finding also showed that the ascorbate pathway was not ethylene dependent, or at least not at this stage of fruit growth.

In contrast to the findings for ascorbate, total antioxidant activity in the fruit studied measured using the DPPH method, significantly increased during the first weeks of storage for both the control and 1-MCP-treated fruit. This showed that ascorbate
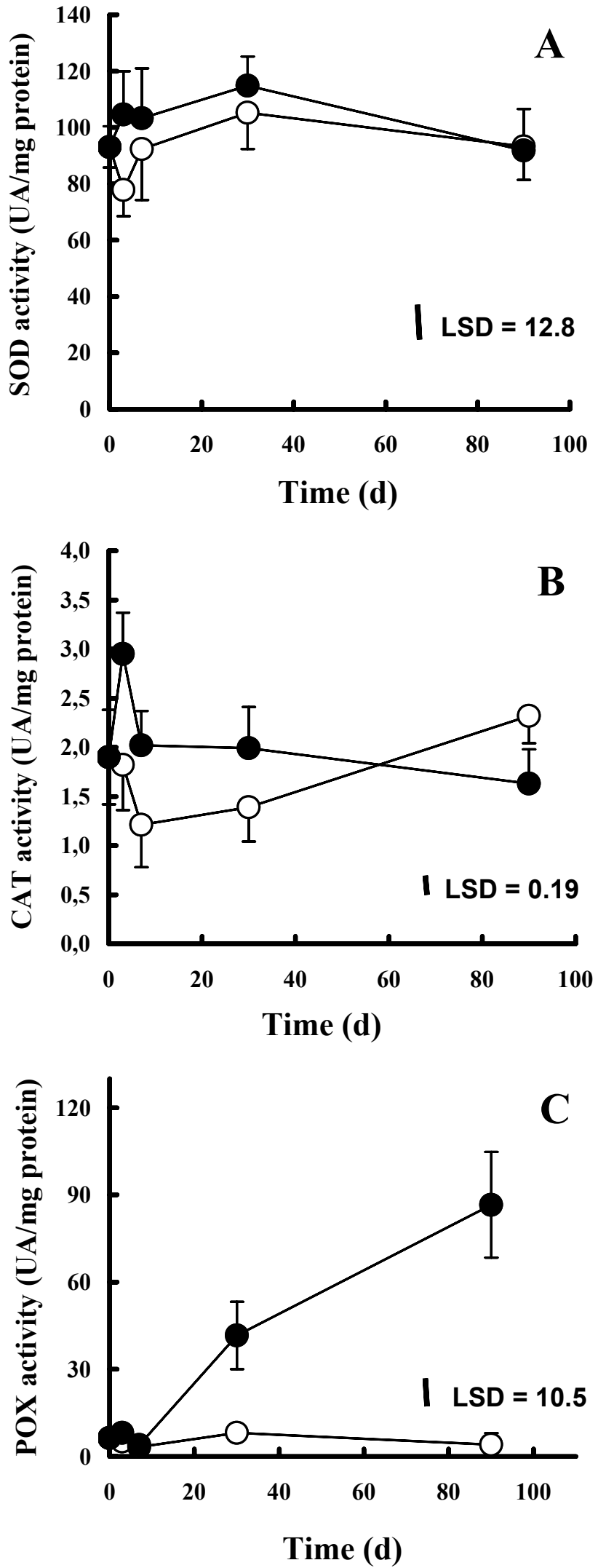

Fig. 2. Changes in the activity of (A) superoxide dismutase (SOD), (B) catalase (CAT), and (C) peroxidase (POX) in 'Golden Smoothee' apples treated with 1-MCP during cold storage; $(\square)$ control fruit, $(\bigcirc)$ fruit treated with $625 \mathrm{~nL} \cdot \mathrm{L}^{-1}$ $1-\mathrm{MCP}$. Each point represents the mean \pm SD of six different fruit; bar $=$ LSD at $P=0.05$. 

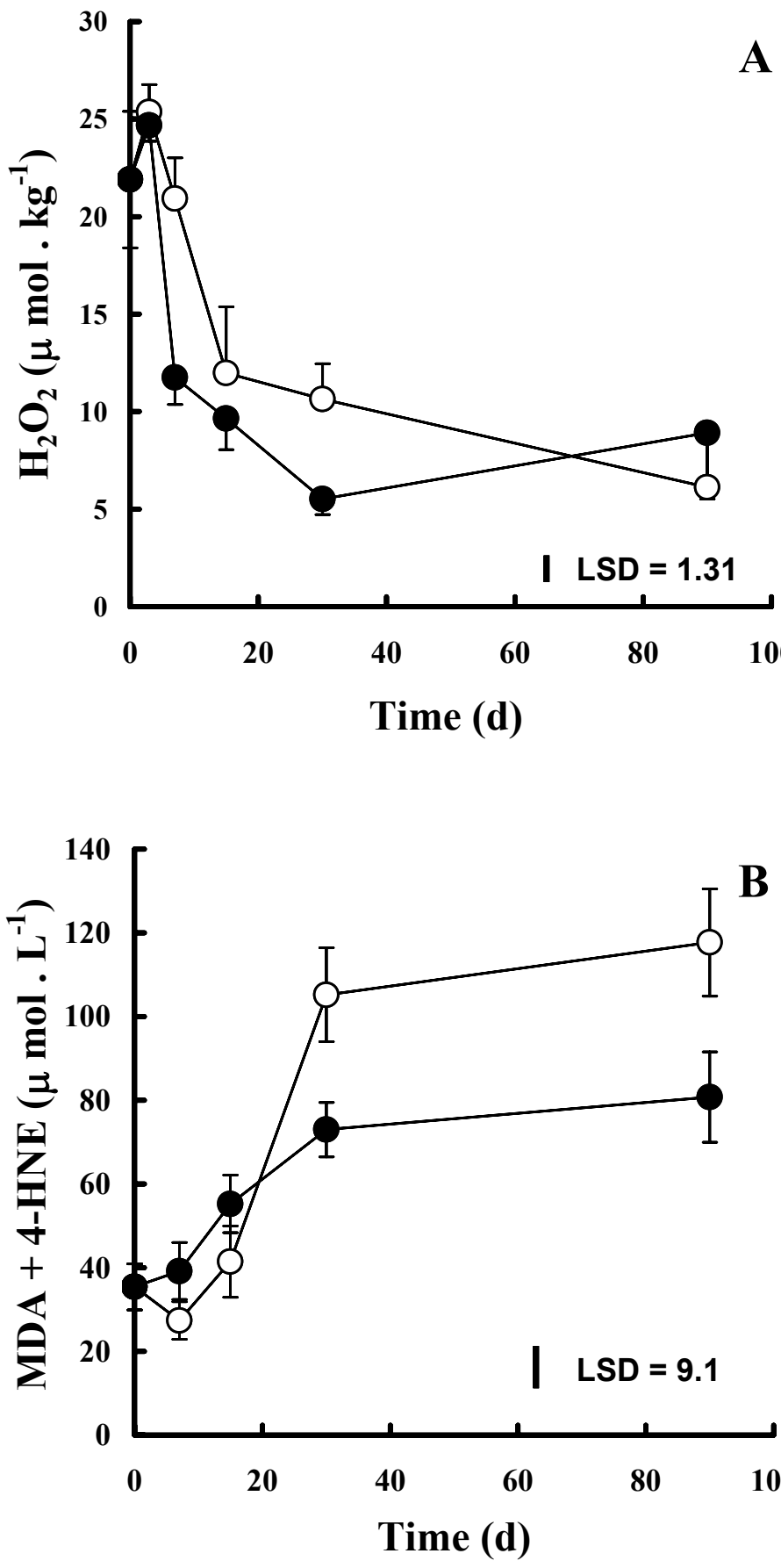

Fig. 3. Changes (A) in the levels of hydrogen peroxide and $(\mathbf{B})$ in the levels of peroxidative markers malonaldehyde (MDA) and 4-hydroxyalkenals (4-HNE) in 'Golden Smoothee' apples treated with 1-MCP during cold storage; ( $\square$ ) control fruit, (O) fruit treated with $625 \mathrm{~nL} \cdot \mathrm{L}^{-1} 1$-MCP. Each point represents the mean \pm SD of six different fruit; bar $=$ LSD at $P=0.05$.

was not the most important factor in determining total antioxidant activity in 'Golden Smoothee' fruit. Other constituents such as phenols, sugars and pigments are also likely to be involved. It is now widely recognized that ripening triggers important physicochemical changes in fruit (Seymour et al., 1993). Sugar levels tend to increase, mainly because of the depolymerization of starch. Total phenol content does not change but lignin becomes more soluble. Except for chlorophyll, the content of carotenoids and other pigments increased: this was especially noticeable in the peel, but was also to a certain extent observed in the pulp. All these metabolic changes were consistent with the increase in total antioxidant activity at the beginning of the ripening process reported in this work. More work is needed to determine the exact weight that each of these compounds plays in the context of antioxidant activity. This information will be of great interest and will help to better understand the dietary characteristics of apples.

This is the first time, to the best of our knowledge, that such a 1-MCP-related change in antioxidant potential has been described in apple pulp. A similar relation was previously reported in 'Empire' and 'Delicious' apples by MacLean et al. (2003), but in those cases changes in antioxidant potential were analyzed in apple peel in relation to scald development.

The effective destruction of active oxygen species (AOS) requires the action of several antioxidant enzymes acting concomitantly with non-enzymatic antioxidants. The superoxide radical $\left(\mathrm{O}_{2}^{--}\right)$is efficiently converted to $\mathrm{H}_{2} \mathrm{O}_{2}$ by the action of superoxide dismutase (SOD), or is directly converted via the oxidation of ascorbate. The main enzymes responsible for converting $\mathrm{H}_{2} \mathrm{O}_{2}$ to water are catalase (CAT) and peroxidase (POX). To better estimate changes in antioxidant metabolism related with the 1-MCP treatment, we also determined the changes in these enzymatic activities during storage. Only a few changes in SOD activity were observed for 'Golden Smoothee' apples in both control and 1-MCP-treated fruit. In contrast, a transitory but significant peak in CAT activity and a very sharp increase in POX activity were observed in 1-MCP-treated fruit. Such an increase in POX activity is consistent with greater resistance to oxidative stress (Bowler et al., 1992).

Similar results with regard to antioxidant enzymes were found in 1-MCP-treated 'Blanquilla' pears (Larrigaudiere et al., 2004). This similarity of behavior suggests that this increase in enzymatic antioxidant potential and especially in POX activity in fruit treated with 1-MCP is not crop specific, but reflects a general metabolic change that is either directly or indirectly associated with ethylene metabolism.

The mechanism by which $\mathrm{H}_{2} \mathrm{O}_{2}$ promotes senescence has already been clearly established (Thompson, 1985). Alone, $\mathrm{H}_{2} \mathrm{O}_{2}$ is relatively unreactive, but combined with $\mathrm{O}_{2}$ - it may form the radical hydroxyl $(\mathrm{OH} \cdot)$, which is a powerful oxidant. Unless metabolized, this product may cause significant metabolic changes via processes such as lipid peroxidation (Halliwell and Gutteridge, 1989). In order to determine if the previously observed changes in antioxidant potential were or were not capable of preventing lipid peroxidation in 'Golden Smoothee' apples, we also analyzed changes in $\mathrm{H}_{2} \mathrm{O}_{2}$ levels and peroxidation markers (MDA and 4$\mathrm{HNE}$ ). Although the control and 1-MCP-treated fruit exhibited similar changes in $\mathrm{H}_{2} \mathrm{O}_{2}$ and peroxidation marker levels during storage, absolute levels always remained lower for 1-MCP-treated fruit. This could be interpreted as reflecting a smaller quantity of peroxidative damage in 1-MCP-treated fruit, which in turn might as previously reported be related to specific changes in antioxidant potential and especially in POX activity.

From its effects on ethylene receptors, 1-MCP treatment is known to inhibit ripening and to help maintain fruit quality during storage and shelf life (Blankenship and Dole, 2003). In 'Golden Smoothee' apples, the 1-MCP treatment also significantly reduced ethylene production throughout the experimental period. Treated fruit remained significantly firmer and showed higher acidity, even during shelf life (results not shown). These differences in quality parameters were obviously ethylene dependent. But what about the changes in antioxidant potential? Does 1-MCP act directly 
through its action upon ethylene production? Does 1-MCP act in a more subtle way on antioxidant pathways? Further research is needed to explain this action. This will be of great interest and will help us to better understand the physiological effects of 1MCP treatment in climacteric fruit.

\section{Literature Cited}

Bailly, C., A. Benamar, F. Corbineau, and D. Come. 1996. Changes in malonaldehyde content and in superoxide dismutase, catalase and glutathione reductase activities in sunflower seeds as related to deterioration during accelerated aging. Physiol. Plant. 97:104-109.

Blankenship, S.M. and J.M. Dole. 2003. 1-Methylcyclopropene: A review. Postharvest Biol. Technol. 28:1-25.

Borracino, G. L. Mastropasqua, S. De Leonardis, and S. Dipierro S. 1994. The role of ascorbic acid system in delaying the senescence of oat (Avena sativa L.) leaf segments. J. Plant Physiol. 144:161-166.

Bowler, C.M., M. van Montagu, and D. Inzé. 1992. Superoxide dismutase and stress tolerance. Ann. Rev. Plant Physiol. Plant Mol Biol. 43:83-116.

Bradford, M. 1976. A rapid and sensitive method for the quantification of microgram quantities of protein utilizing the principle of protein-dye binding. Anal. Biochem. 72:248-254.

Brubaker, G., W. Müller-Mullot, and D. Southgate. 1985. Methods for determination of vitamins in food. Recommended by COST 91. Elsevier, London.

Clairbone, A. 1985. Catalase activity, p. 283-284. In: R. Greenwald (ed.). Handbook of methods for oxygen radical research. CRC Press, Boca Raton, Fla.

Fan, X., S.M. Blankenship, and J.P. Mattheis. 1999a. 1-Methylcyclopropene inhibits apple ripening. J. Amer. Soc. Hort. Sci. 124:690-695.

Fan, X., S.M. Blankenship, and J.P. Mattheis. 1999b. Development of apple superficial scald, soft scald, core flush, and greasiness is reduced by MCP. J. Agr. Food Chem. 47:3063-3068.

Foyer, C., M. Lelandais, E. Edwards, and Mullineaux P. 1991. The role of ascorbate in plants, interactions with photosynthesis and regulatory significance, p. 131-144. In: E. Pell and K. Steffen (eds.). Active oxygen/oxidative stress and plant metabolism. Amer. Soc. Plant Physiol., Rockville, Md.

Giannopolitis, C. and N. Ries. 1977. Superoxide dismutases I: Occurrence in higher plants. Plant Physiol. 59:309-314.

Johnston, J.W., E.W. Hewett, and M.L.A.T.M. Hertog. 2002. Postharvest softening of apple (Malus domestica) fruit: A review. N.Z. J. Crop
Hort. Sci. 30:145-160

Halliwell, B. and J. Gutteridge. 1989. Free radicals in biology and medicine. Clarendon Press, Oxford, U.K.

Kader,A.A. 1995. Regulation of fruit physiology by controlled/modified atmospheres. Acta Hort. 398:59-70.

Kondo, S., K. Tsuda, N. Muto, and J. Veda. 2002. Antioxidative activity of apple skin or flesh extracts associated with fruit development on selected apple cultivars. Scientia Hort. 96:177-185.

Larrigaudière, C., R. Vilaplana, Y. Soria, and I. Recasens. 2004. Oxidative behaviour of Blanquilla pears treated with 1-methylcyclopropene during cold storage. J. Sci. Food Agr. 84:1871-1877.

Lidster, P.D., G.D. Blanpied, and R.K. Prange. 1990. Controlled atmosphere disorders of commercial fruits and vegetables. Agr. Can. Publ. 1947: E, Communications Branch, Agr. Can., Ottawa, Ont., Canada.

Lurie, S., E. Fallik, A. Handros, and R. Shapira. 1997. The possible involvement of peroxidase in resistance to Botrytis cinerea in heattreated tomato fruit. Physiol. Mol. Plant Pathol. 50:141-149.

McLean, D.D., D.P. Murr, and J.R. DeEll. 2003. A modified total oxyradical scavenging capacity assay for antioxidants in plant tissues. Postharvest Biol. Technol. 29:183-194.

Pintó, E., I. Lentheric, M. Vendrell, and C. Larrigaudière. 2001. Role of fermentative and antioxidants metabolisms in the induction of core-browning in controlled-atmosphere stored pears. J. Sci. Food Agr. 81:364-370.

Seymour, G., J. Taylor, and A. Tucker (eds.). 1993. Biochemistry of fruit ripening. Chapmann and Hall, London.

Sisler, E.C., E. Dupille, and M. Serek. 1996. Effects of 1-methylcyclopropene and methylcyclopropene on ethylene binding and ethylene action on cut carnation. Plant Growth Regulat. 18:169-174.

Sisler, E.C. and M. Serek. 1997. Inhibitors of ethylene responses in plants at the receptor level: Recent developments. Physiol. Plant. 100:577-582.

Thompson, J.E. 1985. Physical changes in membranes of senescing and environmentally stressed plant tissues, p. 85-108. In: M. Shinitzky (ed.). Physiology of membrane fluidity, Vol. II. CRC Press, Boca Raton, Fla.

Veltman, R., M. Sanders, S. Persijn, H. Peppelenbos, and J. Oosterhaven. 1999. Decreased ascorbic acid levels and brown core development in pears. Physiol. Plant. 107:39-45.

Wimalasiri, P. and R. Wills. 1983. Simultaneous analysis of ascorbic and dehydroascorbic acid in fruit and vegetables by high-performance liquid chromatography. J. Chromatogr. 256:368-371. 